\title{
Editorial
}

\section{Red Blood Cell and Platelet Indices: A Potential Biomarker for Panic Disorder}

Panic disorder, a type of anxiety disorder is characterized by recurrent, unexpected panic attacks that are not related to a particular situation. It is a common and debilitating psychiatric condition, which may or may not be associated with agoraphobia and other anxiety disorders. ${ }^{[1]}$ Panic disorder is often confused with medical emergencies such as angina, myocardial infarction, and asthma, in emergency settings. The diagnosis of panic disorder primarily relies on clinical history, as currently there is limited or no role of genetic, laboratory tests, and imaging in diagnosing panic disorder. ${ }^{[2]}$

This issue of Journal of Neuroscience in Rural Practice includes a paper titled "Mean Platelet Volume and Platelet Distribution Width Level in Patients with Panic Disorder."[3] In this paper, authors have investigated the relationship between platelets reactivity indicators such as mean platelet volume (MPV), platelet distribution width (PDW), and platelet count; red blood cell (RBC) indices like red cell distribution width (RDW) and RBC count and Panic disorder. The study found increased PDW and RDW in patients with panic disorder compared to healthy controls.

This is in line with the growing interest in studying biomarkers like blood cells and peripheral blood stem cells for diagnosing panic disorder, ${ }^{[4,5]}$ differentiating comorbidities associated with Panic disorders measuring serum ghrelin levels and lipid profile ${ }^{[6]}$ and predicting development of psychiatric comorbidities in cases of panic disorders using biological serum markers such as tetranectin and creatine kinase MB. ${ }^{[7]}$ A study by Asoglu et al., found that MPV and RDW were significantly higher in the patients with panic disorder. ${ }^{[4]}$ Platelets activation and changes in reactivity indicators have been linked to chronic stress, cardiovascular condition, nutritional deficiencies, and various other medical conditions. Measurement of serotonin level, platelet proinflammatory and immune-modulatory secretory compounds such as platelet factor-4, P-selectin and $\beta$-thromboglobulin, monoamine oxidase activity and platelet activity indicators may hold key for future development of biomarkers for diagnosis of various chronic stress-related psychiatric conditions. ${ }^{[8]}$ Although aim of studying biomarkers is to improve accuracy of diagnosis and treatment outcome, in psychiatric conditions diagnosis is mainly clinical so biomarkers should be used judiciously. In fact clustering of positive biomarkers may help defining and classifying a group of psychiatric disorders. Further research on biomarkers in psychiatry should be focus on large set of the clinical population, with standardization of biomarkers, specificity and their relevance in clinical practice. ${ }^{[9]}$

In this regard, role of measurement of RDW and PDW as a potential biomarker for panic disorders needs further exploration with robust research design and methodology.
There is a potential role for investigation of other peripheral biomarkers in panic disorder as well.

\section{Roshan Bhad}

Department of Psychiatry, All India Institute of Medical Sciences, New Delhi, India

\author{
Address for correspondence: Dr. Roshan Bhad, \\ Department of Psychiatry, Room No. 4096, $4^{\text {th }}$ Floor, \\ Academic Block, All India Institute of Medical Sciences, \\ Ansari Nagar, New Delhi - 110 029, India. \\ E-mail: drroshansindia@gmail.com
}

\section{REFERENCES}

1. Taylor CB. Panic disorder. BMJ 2006;332:951-5.

2. Locke AB, Kirst N, Shultz CG. Diagnosis and management of generalized anxiety disorder and panic disorder in adults. Am Fam Physician 2015;91:617-24.

3. Ransing RS, Patil B, Grigo O. Mean platelet volume and platelet distribution width level in patients with panic disorder. J Neurosci Rural Pract 2017;8:174-8.

4. Asoglu M, Aslan M, Imre O, Kivrak Y, Akil O, Savik E, et al. Mean platelet volume and red cell distribution width levels in initial evaluation of panic disorder. Neuropsychiatr Dis Treat 2016;12:2435-8.

5. Jablonski M, Mazur JK, Tarnowski M, Dolegowska B, Pedziwiatr D, Kubis E, et al. Mobilization of peripheral blood stem cells and changes in the concentration of plasma factors influencing their movement in patients with panic disorder. Stem Cell Rev 2016. DOI 10.1007/s12015-016-9700-6. [Epub ahead of print].

6. Gul IG, Cumurcu BE, Karlidag R, Turkoz Y. Ghrelin and lipid levels in panic disorder before and after treatment and their relationship with agoraphobia. Psychiatr Danub 2015;27:250-8.

7. Gottschalk MG, Cooper JD, Chan MK, Bot M, Penninx BW, Bahn S. Serum biomarkers predictive of depressive episodes in panic disorder. J Psychiatr Res 2016;73:53-62.

8. Koudouovoh-Tripp P, Sperner-Unterweger B. Influence of mental stress on platelet bioactivity. World J Psychiatry 2012;2:134-47.

9. Boksa P. A way forward for research on biomarkers for psychiatric disorders. J Psychiatry Neurosci 2013;38:75-7.

This is an open access article distributed under the terms of the Creative Commons Attribution-NonCommercial-ShareAlike 3.0 License, which allows others to remix, tweak, and build upon the work non-commercially, as long as the author is credited and the new creations are licensed under the identical terms.

\begin{tabular}{|l|l|}
\hline \multicolumn{2}{|c|}{ Access this article online } \\
\hline Quick Response Code: & Website: \\
\hline
\end{tabular}

How to cite this article: Bhad R. Red blood cell and platelet indices: A potential biomarker for panic disorder. J Neurosci Rural Pract 2017;8:164. 